\title{
Research on the Relationship between Job Embeddedness and Voluntary Turnover of Internet R\&D Personnel
}

\author{
Siyu Zhang \\ Wuhan University of Technology \\ Wuhan, China \\ zsywhut@foxmail.com
}

\begin{abstract}
With the development of economy and the adjustment of industrial structure, the position of staff in the enterprise is becoming increasingly important, especially for Internet companies, where $R \& D$ personnel are core resources. Therefore, in the increasingly fierce competition for talents, how to control the voluntary turnover rate of $R \& D$ personnel is the key to the healthy development of enterprises. Based on the theory of job embeddedness, this paper uses the job embeddedness-voluntary turnover method to analyze the Internet $R \& D$ personnel, and then analyzes the data of empirical study with the help of the spss22.0. The results show that there is no significant influence between off-the-job embeddedness and the turnover tendency of Internet R\&D personnel. On-the-job embeddedness is negatively correlated with voluntary turnover of Internet $R \& D$ personnel. Besides, the degree of correlation between off-the-job embeddedness and employee voluntary turnover is lower than on-the-job embeddedness. According to the results, this paper proposes a few countermeasures for improving staff's embeddedness degree.
\end{abstract}

Keywords-job embeddedness; voluntary turnover; $R \& D$ personnel

\section{INTRODUCTION}

Modern enterprise management believes that human resource is not only one type of capital, but also one of the most important factors for enterprises to survive and develop. With the rapid development of the third industry, a large number of new forms enterprises have sprung up. With the increasing demand for talents, the competition for talents among enterprises is more and more fierce as well. However, high training cost and Replacement cost makes the company miserable. The longer employees contribute to the organization, the more benefits they could get from employees. Therefore, no matter what organization it is, attracting talents alone is absolutely not enough, how to retain the talents is the key to keep the core competitiveness.

This paper takes Internet $R \& D$ personnel as the research object, through rebuilding the relational model between job embeddedness and employee turnover, designing the questionnaire and analyzing the data. Based on these analyses, hoping to help the Internet companies better understand the former factors of R\&D personnel's voluntary turnover. Then put forward the corresponding solutions to help Internet companies better to control the active turnover rate within a reasonable scope, thus reducing recruitment costs and risk.

\section{THE REVIEW OF THE RESEARCH ON THE JOB EMBEDDEDNESS}

In 2001, Mitchell and Lee put forward the concept of job embeddedness for the first time, and conducted in-depth research on the relationship between job embeddedness and employee voluntary turnover by Empirical Study [1]. James (2007) firstly proposed the 'shock' variable to link job embeddedness and expansion model together [2]. Mallol (2007) studied the impact of intercultural race personnel's job embeddedness on voluntary turnover. Crossley and Bennett (2007) improved the measurement method and put forward that "The predictive power of overall measurement to turnover intention is better than synthetic measurement" [3].

Although starting later than abroad, domestic research still has come a long way. Zhang Mian and Zhang De (2002) studied the reasons for employee turnover in IT enterprises from the perspective of job embeddedness [4]. Yang Chun Jiang (2010) mainly discussed the effect of "shock" and analyzed the relationship between image theories, job embeddedness and "expanding" model [5]. Shu Fei (2008) validated the effectiveness of the job embeddedness model in the Chinese context of the employee turnover tendency through empirical study [6]. Mai Yi Yuan (2009) combined the job embeddedness theory with the actual case. She analyzed the impact of the job embeddedness theory on the technology employees who leave to start their own businesses [7].

Despite its non-subjective and more realistic advantages, job embeddedness theory has become one of the hottest topics in the field of organizational behavior at present. However, this paper argues that it is also urgently needed to be enriched and developed in many aspects. There are three main directions: The first is to increase job embeddedness theory of the antecedent factors. Second, considering the cross-cultural factors, to constantly improve the measurement scales through the optimization of measuring tools and methods. Third, analyze the contradiction between organizational embeddedness and community embeddedness, and put forward corresponding management suggestions. 


\section{RESEARCH DESIGN}

\section{A. Research hypotheses}

At present, individuals could not live independent from the environment. It is inevitably to establish various formal or informal connection with the people or objects around them and make a sense of dependence. With the increase of links, there will be more restraints from leaving the existing situation. What's more, employees experience compatibility and comfort in organizations and communities with high matching degree. When he leaves the environment, he has to abandon his existing interest and assume the risks of an uncertain future. Given these sacrifices, employees will not easily make a decision to leave the job. So put forward the hypotheses:

H1: off-the-job embeddedness is negatively correlated with voluntary turnover of Internet R\&D personnel.

H1a: community fit is negatively correlated with voluntary turnover of Internet R\&D personnel.

H1b: community links is negatively correlated with voluntary turnover of Internet R\&D personnel.

H1c: community sacrifice is negatively correlated with voluntary turnover of Internet R\&D personnel.

H2: on-the-job embeddedness is negatively correlated with voluntary turnover of Internet R\&D personnel.

H2a: organization fit is negatively correlated with voluntary turnover of Internet R\&D personnel.

H2b: organization links is negatively correlated with voluntary turnover of Internet R\&D personnel.

H2c: organization sacrifice is negatively correlated with voluntary turnover of Internet R\&D personnel.

At present, our country's Internet R\&D personnel tend to be younger, and most of the employees are unmarried or have married but had no child. Relative to the stable living environment, they pay more attention to work environment and job opportunities more. Besides, the development of our community is far from perfect in western countries, so it cannot provide more convenience for employees. So put forward the hypothesis:

H3: off-the-job embedding is lower relevant to employee turnover than on-the-job embedding.

\section{B. Variables and theoretical model}

This paper takes Internet R\&D personnel as the research object, takes job embedding theory as the theoretical basis, takes organizational fit, organizational links, organizational sacrifices, community fit, community links, community sacrifices as independent variables, takes employee turnover intention as a dependent variable. Through the construction of the model, this paper explains the predictive effect of job embeddedness in six dimensions on the initiative of Internet developers. The specific model shown below:

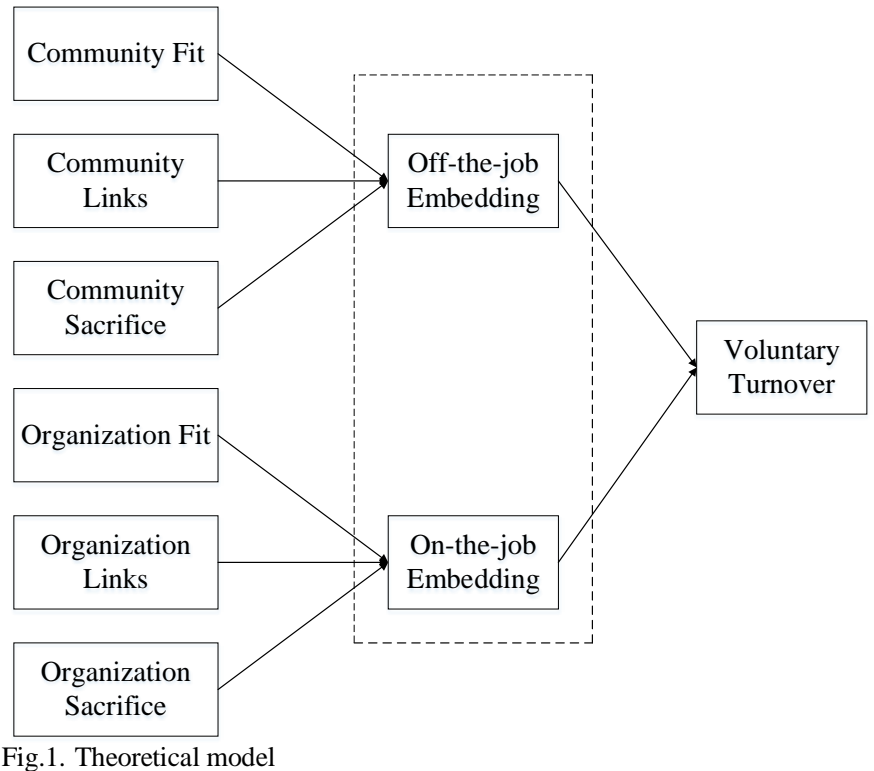

C. Questionnaire design

The entire questionnaire is divided into three parts:

The first part: personal basic information. Mainly include gender, age, academic qualifications and other basic information.

The second part: job embeddedness scale. This scale mainly refers to Mitchell \& Lee job embeddedness scale. However, take into account the different roles of community factors in cross-cultural context. The questionnaire was revised and supplemented according to Liang Xiao Wei's point of view. The scale includes 34 topics and is evaluated according to the Likert scale.

The third part: the turnover intention scale. Considering the behavioral characteristics of the research object, this paper selects the scale developed by Farh (1998).This scale has been verified by Zhang Mian (2001) to prove that it has good internal consistency and convergent validity. There are only four questions, which are simple and easy to understand. And all of them are calculated by Likert scale.

\section{EMPIRICAL ANALYSIS}

\section{A. Data source}

This research mainly aims at the Internet companies R\&D personnel in Beijing area. A total of 150 formal questionnaires were issued and 134 were returned. The effective rate of the questionnaire recovery was $89.32 \%$. The effective questionnaire was 121 and the effective rate of the questionnaire was $90.3 \%$.

\section{B. Reliability and Validity Analysis of Questionnaire}

This paper analyzed the data of empirical study with the help of the spss22.0. The Cronbach's Alpha of the job embeddedness scale is 0.846 . And organization sacrifice's Cronbach's Alpha is 0.784, organization fit's Cronbach's Alpha is 0.783, organization links' Cronbach's Alpha is 0.658, community fit's Cronbach's Alpha is 0.816, community sacrifice's Cronbach's Alpha is 0.715 , community links' 
Cronbach's Alpha is 0.773. The above data indicates that the reliability of the scale is better. Although the Cronbach's Alpha of organizational links and community sacrifice is low, it is also between 0.65 and 0.75 , which is acceptable. At the time of validity analysis, the KMO of on-the-job embeddedness is 0.702 , while off-the-job embeddedness' KMO is only 0.610 . And the turnover intention scale is 0.779 . It shows that the validity of job embeddedness scale and turnover intention scale are not bad. Therefore, it can be considered that the scale of this study is in line with the needs of the research and can carry out the next research.

\section{Regression analysis}

TABLE I. REGRESSION ANALYSIS RESULTS

\begin{tabular}{|c|c|c|c|c|c|}
\hline \multirow{2}{*}{ Model } & \multicolumn{2}{|c|}{$\begin{array}{c}\text { Non-standardized } \\
\text { Coefficient }\end{array}$} & $\begin{array}{c}\text { Standard } \\
\text { Coefficient }\end{array}$ & \multirow{2}{*}{ T } & \multirow{2}{*}{ Sig. } \\
\cline { 2 - 5 } & $\boldsymbol{B}$ & $\begin{array}{c}\text { Standard } \\
\text { error }\end{array}$ & Beta & & \\
\hline Constant & 3.707 & .459 & & 8.074 & .000 \\
\hline $\begin{array}{c}\text { On-the-job } \\
\text { Embeddedness }\end{array}$ & -.343 & .139 & -.236 & -2.472 & .015 \\
\hline $\begin{array}{c}\text { Off-the-job } \\
\text { Embeddedness }\end{array}$ & .104 & .124 & .080 & .841 & .402 \\
\hline
\end{tabular}

a. dependent variable: Turnover tendency

As we can see, the regression coefficient of on-the-job embeddedness and off-the-job embeddedness is $-0.343,0.104$. $\mathrm{T}$ value of them is $-2.472,0.841$. $\mathrm{P}$ value is $0.015,0.402$. These results prove that on-the-job embeddedness is negatively correlated with voluntary turnover of Internet R\&D personnel. There is no significant influence between off-the-job embeddedness and the turnover tendency. Therefore, $\mathrm{H} 1$ is not tenable, $\mathrm{H} 2$ is tenable and $\mathrm{H} 3$ is tenable. At the same time, regression analysis equations can be established like this:

Turnover tendency=3.707-0.343 on-the job embeddedness +0.104 off the job embeddedness

TABLE II. REGRESSION ANALYSIS RESULTS

\begin{tabular}{|c|c|c|c|c|c|}
\hline \multirow{2}{*}{ Model } & \multicolumn{2}{|c|}{$\begin{array}{c}\text { Non-standardized } \\
\text { Coefficient }\end{array}$} & $\begin{array}{c}\text { Standard } \\
\text { Coefficient }\end{array}$ & \multirow{2}{*}{ T } & \multirow{2}{*}{ Sig. } \\
\cline { 2 - 5 } & $\boldsymbol{B}$ & $\begin{array}{c}\text { Standard } \\
\text { error }\end{array}$ & Beta & & \\
\hline Constant & 3.554 & .424 & & 8.384 & .000 \\
\hline $\begin{array}{c}\text { organization } \\
\text { sacrifice }\end{array}$ & -.0 .17 & .119 & -.015 & -.142 & .887 \\
\hline organization fit & -.264 & .123 & -2.33 & -2.142 & .0 .34 \\
\hline organization links & -.335 & 0.090 & -.322 & -3.718 & 0.000 \\
\hline community fit & 0.33 & .068 & .041 & .480 & .632 \\
\hline community sacrifice & -.339 & .127 & .290 & -2.663 & .009 \\
\hline community links & -.110 & .087 & -.110 & -1.265 & .209 \\
\hline
\end{tabular}

b. dependent variable: Turnover tendency

Through the analysis, the regression results show that the regression coefficient of organization sacrifice, organization fit, organization links, community fit, community sacrifice, community links is $-0.017,-0.264,-0.335,0.033,-0.339$, -0.110 . $T$ value is equal to $-0.142,-2.142,-3.718,0.480,-2.663$, -1.265 . $\mathrm{P}$ value is equal to $0.034,0.000,0.632,0.009,0.209$. These results prove that organization fit, organization links, community sacrifice is negatively correlated with voluntary turnover of Internet R\&D personnel. While the impact of organizational sacrifice, community fit and community links on the turnover tendency is not significant. At the same time, regression analysis equations can be established like this:

Turnover tendency=3.554-0.017 organization sacrifice -0.264 organization fit- 0.335 organization links +0.033 community fit-0.339 community sacrifice- 0.110 community links

\section{CONCLUSIONS AND COUNTERMEASURES}

\section{A. Research conclusion}

Through the previous statistical analysis, this study has completed the verification of the hypotheses. In order to see the support of the hypotheses in this study more intuitive, we summarized the empirical analysis results into the table:

TABLE III. SUMMARY OF RESEARCH RESULTS

\begin{tabular}{|l|c|}
\hline \multicolumn{1}{|c|}{ Research Hypotheses } & $\begin{array}{c}\text { Test } \\
\text { Results }\end{array}$ \\
\hline $\begin{array}{l}\text { H1 off-the-job embeddedness is negatively correlated with } \\
\text { voluntary turnover of Internet R\&D personnel. }\end{array}$ & $\begin{array}{c}\text { not } \\
\text { tenable }\end{array}$ \\
\hline H1a: community fit is negatively correlated with voluntary. & $\begin{array}{c}\text { not } \\
\text { tenable }\end{array}$ \\
\hline $\begin{array}{l}\text { H1b community links is negatively correlated with voluntary } \\
\text { turnover of Internet R\&D personnel. }\end{array}$ & $\begin{array}{c}\text { not } \\
\text { tenable }\end{array}$ \\
\hline $\begin{array}{l}\text { H1c community sacrifice is negatively correlated with voluntary } \\
\text { turnover of Internet R\&D personnel. }\end{array}$ & tenable \\
\hline $\begin{array}{l}\text { H2 on-the-job embeddedness is negatively correlated with } \\
\text { voluntary turnover of Internet R\&D personnel. }\end{array}$ & tenable \\
\hline $\begin{array}{l}\text { H2a organization fit is negatively correlated with voluntary } \\
\text { turnover of Internet R\&D personnel. }\end{array}$ & tenable \\
\hline $\begin{array}{l}\text { H2b organization links is negatively correlated with voluntary } \\
\text { turnover of Internet R\&D personnel. }\end{array}$ & tenable \\
\hline $\begin{array}{l}\text { H2c organization sacrifice is negatively correlated with } \\
\text { voluntary turnover of Internet R\&D personnel. }\end{array}$ & $\begin{array}{c}\text { not } \\
\text { tenable }\end{array}$ \\
\hline $\begin{array}{l}\text { H3 off-the-job embedding is lower relevant to employee } \\
\text { turnover than on-the-job embedding. }\end{array}$ & tenable \\
\hline
\end{tabular}

\section{B. Research on countermeasures}

1) Strengthen the connection between work and non-work

Broaden the channels of communication, establish effective communication mechanisms and enhance communication between employees and enterprises. Establish good working teams and working relationships in the organization to achieve close relations. Actively mobilize the sense of ownership of employees and implement the internal push mechanism. Set up work or interest groups to give employees access to more people in other sectors by establishing cross-departmental or technology-sharing groups.

2) Improve the match between the employees and the organization

Identifying employees who are more in line with the organizational culture and organizational situation. Looking for the right persons rather than talents. Paying more attention to non-financial compensation, the performance and growth of 
employees in work; respect individual values and increase mental energizing; establish reasonable ranks and salaries ascent channel. Setting less requests on the path of technology. Making sure that everyone can automatically promote as long as he/she reaches the standard.

3) Increase the community cost of employee turnover

Help employees solve household registration problems by providing green channels for developers to locate or handle residence permits. This will help them integrate into the working environment more quickly. What's more, companies can provide help for employees to rent or buy houses through housing subsidies or interest-free home loan.

\section{ACKNOWLEDGMENT}

The author thanks the financial support from the National Social Science Foundation of China (Grant No.15ZDC022; Grant No.17BGL209) and National Natural Science Foundation of China (Grant No.71373199).

\section{REFERENCES}

[1] Mitchell T. R., Holtom B. C., Lee T. W. "Why People Stay: Using Job Embeddedness to Predict Voluntary Turnover," Academy of Management Journal, 2001, pp. 1102-1121.

[2] Rong Liu, Shengiia Xue, ” Work embedding research review and prospect”, Science and Technology Management Research, 2010, pp. 276-278+248.

[3] Crossley C.D, Bennett R.J, Jex S.M., Burnfield J.L , "Development of a Global Measure of Job Embeddedness and Integration into a Traditional Model of Voluntary Turnover,” Journal of Applied Psychology,2007, pp. 1031- 1042

[4] Mian Zhang, Shuzhuo Li, "A review of the psychological motivation model of employees' active turnover ,"Advances in Psychological Science,2002, pp. 330-341.

[5] Chunjiang Yang, Qinhai Ma, Xianfeng Zeng, "Predicting Turnover from the Perspective of Retention: A Review of Research on Job Embeddedness," Nankai Business Review, 2010, pp 105-118+131.

[6] Fei Shu, "Study on Prediction Effectiveness of Employee Embeddedness Model on Employee Turnover Intentions," Nanjing Normal University, 2008.

[7] Yiyuan Mai, Haoan Zhou, Lin Mei, "The Impact of Job Embedding on the Turnover and Entrepreneurship Activities of Technological Workers,” Nankai Business Review, 2009, pp.67-77. 